\title{
Judicialização de políticas públicas: uma análise da intervenção do Poder Judiciário na elaboração, implantação e execução de políticas públicas à luz da jurisprudência do STF e do STJ
}

\author{
Erick Miranda da Silva \\ Tabira de Souza Andrade \\ Márcia Maria de Medeiros Travassos Saeger
}

Judicialização de políticas públicas: uma análise da intervenção do Poder Judiciário na elaboração, implantação e execução de políticas públicas à luz da jurisprudência do STF e do STJ

Resumo. O Estado é a organização político-jurídico-administrativa de determinado povo, que tem a missão de empregar esforços na satisfação das necessidades e interesses da coletividade. O Poder Judiciário intervém junto aos demais Poderes com o intuito de compeli-los à implantação das políticas públicas. Diante da jurisprudência adotada pelo STF e STJ, procuramos verificar quais os princípios e valores que legitimam tal ingerência, em detrimento da separação político-funcional dos poderes constituídos da República. Para tanto, realizamos uma pesquisa qualitativa em documentos internos destes dois tribunais, analisando decisões judiciais acerca da intervenção jurisdicional na efetivação de políticas públicas, selecionando-se nove. Identificamos, ao final, que essa atuação do Judiciário mostra-se importante exceção ao sistema de independência e harmonia dos poderes estatais, mas necessária quando não é assegurada aos cidadãos a garantia do mínimo necessário a uma vida digna.

Palavras-chave: Estado. Políticas Públicas. Judicialização.

Legalization of public policies: an analysis of the intervention of the judiciary in the making, implementation and execution of public policies in the light of the STF and the STJ

Abstract. The state is the political-legal and administrative organization of particular people, whose mission is to employ efforts in meeting the needs and interests of the community. The Judiciary intervenes together with the other Powers in order to compel them the implementation of public policies. Facing the jurisprudence adopted by the $S T F$ and $S T J$, we seek check what are the principles and values that legitimize such interference, over the political and functional separation of the Powers constituted of the Republic. Therefore, we conducted a qualitative research on internal documents of these two courts, analyzing court decisions about court intervention in the execution of public policies, selecting nine. We identified, at the end, that the judicial actions shows an important exception to the system independence and harmony of the state powers, but necessary when it is not guaranteed to citizens to guarantee of the minimum necessary for a decent life.

Key-words: State. Public Policy. Legalization. 


\section{Introdução}

O estudo da Ciência Política aponta o Estado como sendo a organização político-jurídico-administrativa de determinado povo, sobre uma base territorial, dotada de soberania. Esta organização tem seu fundamento e legitimidade na outorga do poder político pelo povo aos agentes incumbidos da direção dos assuntos políticos dessa mesma sociedade. Em razão disto, tais agentes tem a missão, conferida pela sociedade formadora do Estado, de empregar esforços na concretização das necessidades e interesses do povo, que é o fim do ente estatal, ou seja, o bem comum (DALARE, 1998).

Visando ao atendimento desses interesses e necessidades, os agentes públicos lançam mão de diversos mecanismos para apuração das carências sociais, a fim de que os recursos sejam mais bem empregados e os resultados mais satisfatórios. Dentre estes instrumentos, as chamadas políticas públicas encontram significativo espaço, haja vista serem um conjunto integrado de ações, elaboradas e planejadas através de uma série de estudos e pesquisas, no intuito de identificar, com máxima precisão, quais pontos devem ser atendidos.

Para pôr em prática (implantação e execução) as políticas públicas, definidas no plano de governo, o Poder Público precisa fazer uso de recursos financeiros e humanos. No que tange aos recursos financeiros, estes são o principal meio de concretização das políticas públicas, em virtude de tudo que o Estado precisa fazer, deve ser através do desembolso desses recursos. Tais recursos financeiros são obtidos principalmente através das receitas captadas pelo pagamento de tributos por parte da sociedade. Contudo, por mais populosa e abastada que seja a sociedade, os valores arrecadados aos cofres públicos são relativamente escassos, e insuficientes para atender a todas as demandas sociais (LEITE, 2012).

Infelizmente, em razão da escassez de recursos financeiros, algumas das políticas públicas não chegam a ser implementadas, deixando de atender a determinada parcela da sociedade. Este fenômeno é chamado de "Reserva do Possível", pois, apenas é possível pôr em prática aquelas ações que sejam indispensáveis ao atendimento das necessidades e interesses sociais. Ocorre que, diante dessa "reserva", surgem alguns questionamentos por parte dos atores sociais, tais como: como são escolhidas as Políticas a serem implementadas? Quais os critérios de seleção? Qual o plano de contingência? Como fica a parcela da população não contemplada pelas ações governamentais?

A fim de responder estas e outras perguntas, várias entidades da sociedade civil ingressam com ações na Justiça, cada uma buscando a implementação da política pública mais adequada à satisfação dos interesses e necessidades do grupo ao qual representa. Essa busca por uma prestação jurisdicional, que torne efetiva a atuação do Estado em determinado setor social, é conhecido hoje como Judicialização das Políticas Públicas ou Controle Social das Políticas Públicas (LEAL, 2005).

A discussão acerca deste fenômeno gira em torno de diversos temas, como o das Finanças Públicas, do Orçamento Participativo, do Ativismo Judicial e o da Separação dos Poderes. À giza dessa multidisciplinaridade de temas relevantes que envolvem a Judicialização das Políticas Públicas, é que o presente tema precisa ser abordado com mais detalhes, a fim de que seja identificado qual o verdadeiro papel do Poder 
Judiciário, através de pronunciamentos judiciais capazes de obter do Poder Executivo a implementação de determinada política pública.

Assim, este trabalho tem o escopo de, através da pesquisa e estudo da jurisprudência consolidada do Supremo Tribunal Federal e do Superior Tribunal de Justiça, órgãos de cúpula do Poder Judiciário brasileiro, verificar quais os principais casos relacionados com o tema proposto, e quais os princípios e normas legais aplicados aos mesmos. Ao final da pretensa pesquisa, seremos capazes de identificar qual o fundamento jurídico adotado por estes órgãos de sobreposição do Judiciário, e até onde se legitima a sua intervenção.

\section{Revisão da literatura}

Quando uma sociedade surge, ou seja, quando um determinado grupo de pessoas (povo) se organiza sobre um determinado lugar (território), é necessária a instituição de uma entidade que represente e congregue todas as vontades daqueles indivíduos que lhe formam. Tal entidade, segundo os postulados trazidos pelos estudos da Ciência Política, é o Estado, que nada mais é do que a organização político-jurídico-administrativa daquele grupo de pessoas que lhe deu origem (AZAMBUJA, 2008).

Nesse sentido, como o Estado conjuga em sua razão de existir as vontades e aspirações das pessoas que lhe compõe, é forçoso reconhecer que sua função precípua é a realização do bem comum, sendo este, em apertada síntese, a maximização dos interesses e necessidades dos indivíduos (sociedade) que compõem o Estado, tomando como premissa básica a Dignidade da Pessoa Humana, a fim de que as ações estatais sejam irradiadas e alcançadas por todos os cidadãos.

Pontual trazer aqui o magistério de Dalare (1998, p.41), acerca do bem comum. Senão vejamos:

Procedendo-se a uma síntese de todas essas ideias, verifica-se que o Estado, como sociedade política, tem um fim geral, constituindo-se em meio para que os indivíduos e as demais sociedades possam atingir seus respectivos fins particulares. Assim, pois, pode-se concluir que o fim do Estado é o Bem Comum, entendido este como o conceituou o Papa João XXIII, ou seja, o conjunto de todas as condições de vida social que consintam e favoreçam o desenvolvimento integral da personalidade humana.

Destarte, podemos entender que o bem comum toma como ponto norteador o Princípio da Dignidade da Pessoa Humana, pois o Estado existe em função do indivíduo e não o contrário. Quando o ente político proclama a Dignidade da Pessoa Humana como princípio orientador de toda a sua atuação, está consagrando um imperativo de justiça social, ou seja, um conjunto de valores civilizatórios incorporado ao patrimônio do cidadão.

Segundo o Ministro do Supremo Tribunal Federal, Luiz Roberto Barroso, a Dignidade da Pessoa Humana, hodiernamente, ostenta significativo espaço no ordenamento jurídico brasileiro e em outros diversos países. Porém, até chegar a este status, percorreu longo caminho. São palavras do professor: 
A dignidade humana tem seu berço secular na Filosofia. Constitui, assim, em primeiro lugar, um valor, que é conceito axiológico, ligado à ideia de bom, justo, virtuoso. Nessa condição, ela se situa ao lado de outros valores centrais para o Direito, como justiça, segurança e solidariedade. É nesse plano ético que a dignidade se torna, para muitos autores, a justificação moral dos direitos humanos e dos direitos fundamentais. Em plano diverso, já com o batismo da política, ela passa a integrar documentos internacionais e constitucionais, vindo a ser considerada um dos principais fundamentos dos Estados democráticos (BARROSO, 2010, p.10).

Desse modo, como o interesse da coletividade (sempre lastreado pela Dignidade da Pessoa Humana) deve ser o guia de toda a sua atuação, ao Estado precisam ser outorgados determinados poderes, para que seja soberano na busca desse fim, ou seja, que não haja nenhum outro poder, interno (interesse particular) ou externo (comunidade internacional), capaz de lhe causar ingerência na condução de seus assuntos. É por isso que o Estado é também chamado de Poder Público, pois é o poder que emana da própria sociedade, através da supremacia do interesse público sobre o particular, para seu único e exclusivo deleite e atendimento.

Acerca da concepção do Estado como forma de poder, mais uma vez se faz pertinente citar as palavras de Dalare (1998, p.42), senão vejamos:

Para a maior parte dos autores o poder é um elemento essencial ou uma nota característica do Estado. Sendo o Estado uma sociedade, não pode existir sem um poder, tendo este na sociedade estatal certas peculiaridades que o qualificam, das quais a mais importante é a soberania. Não há, também, uma distinção muito nítida entre poder de império e soberania, havendo quem identifique o imperium com a soberania no âmbito interno, enquanto que outros entendem como poder de império o que se exerce sobre pessoas.

Contudo, não há como falar em Dignidade da Pessoa Humana e, por via de consequência, em concretização do bem comum da coletividade, sem serem feitas considerações sobre Direitos Fundamentais. Estes formam o conjunto de princípios e valores que garantem a convivência pacífica, digna e igualitária dos indivíduos, independente de quaisquer orientações de cunho religioso, filosófico/ideológico ou político. Podemos colocar desse modo: se a Dignidade da Pessoa Humana é o substrato da atuação Estatal na busca do bem comum, os Direitos Fundamentais são a manifestação político-jurídica de tal busca.

São os Direitos Fundamentais que irão balizar todas as ações do Estado; melhor dizendo, todos os planos de governo, programas e políticas públicas. Independente da agremiação partidária que esteja à frente do comando estatal, deverão sempre seguir os valores e princípios insculpidos pelos Direitos Fundamentais. Sobre esse ponto, citando em seu voto, no julgamento da Ação Declaratória de Inconstitucionalidade $n^{\circ} 2.649$, o constitucionalista contemporâneo José Afonso da Silva, a Ministra do Supremo Tribunal Federal, Cármem Lúcia, explicita a responsabilidade estatal na concretização desses direitos. Observemos:

E, referindo-se, expressamente, ao Preâmbulo da Constituição brasileira de 1988, escolia José Afonso da Silva que 'O Estado Democrático de Direito destina-se a assegurar o exercício de determinados valores supremos. 'Assegurar', tem, no contexto, função 
de garantia dogmático-constitucional; não, porém, de garantia dos valores abstratamente considerados, mas do seu 'exercício'. Este signo desempenha, aí, função pragmática, porque, com o objetivo de 'assegurar', tem o efeito imediato de prescrever ao Estado uma ação em favor da efetiva realização dos ditos valores em direção (função diretiva) de destinatários das normas constitucionais que dão a esses valores conteúdo específico' (ADI 2.649, voto da Rel. Min. Cármen Lúcia, julgamento em 8-5-2008, Plenário, DJE de 17-10-2008).

Desse modo, é através da constitucionalização dos direitos fundamentais que o Estado elege os valores mais relevantes da sociedade que o forma. Em outras palavras, é no texto da Constituição, fundamento de todo seu ordenamento jurídico, que o Estado buscará a direção de toda sua atividade, mormente no que diz respeito à efetivação das condições essenciais para o pleno desenvolvimento dos potenciais humanos. Nesse contexto, o Poder Público deve adotar uma posição proativa frente às necessidades coletivas, buscando assegurar a justiça social.

\subsection{Direitos sociais e políticas públicas}

Dentre os Direitos Fundamentais da pessoa humana, destacam-se aqueles chamados de Direitos Sociais, ou, como alguns autores gostam de chamá-los, Direitos de $2^{a}$ Geração. Surgidos a partir do final da Segunda Guerra Mundial, tais direitos são consubstanciados em prestações positivas oferecidas pelo Poder Público aos indivíduos, as quais visam equilibrar as diferenças sociais existentes nos vários níveis da coletividade. Leivas (2006, p.89) conceitua os Direitos Sociais, aduzindo que os mesmos são:

Direitos a ações positivas fáticas, que, se o indivíduo tivesse condições financeiras e encontrasse no mercado oferta suficiente, poderia obtê-las de particulares, porém, na ausência destas condições e, considerando a importância destas prestações, cuja outorga ou nãooutorga não pode permanecer nas mãos da simples maioria parlamentar, podem ser dirigidas contra o Estado por força de disposição constitucional.

Neste ponto, podemos destacar o direito à Saúde, à Educação, à Moradia, à Seguridade Social etc. São, em verdade, direitos de natureza econômica, social e cultural, que visam assegurar o bem-estar e igualdade entre os cidadãos. Como impõem ao Estado um dever de agir (prestações positivas), é justamente visando ao seu atendimento, que o Poder Público estabelece o seu "Plano de Ação", para a efetiva implantação desses direitos, na busca da justiça social.

É possível percebermos que o debate acerca dos Direitos Sociais confunde-se com o das chamadas políticas públicas, que podem ser visualizadas como a totalidade de ações, metas e planos que os governos (nacionais, estaduais ou municipais) traçam para alcançar o bem-estar da sociedade e o interesse público (bem comum).

Saraiva (2007, p.28) discorre bem, ao traçar, mesmo que sinteticamente, um conceito de políticas públicas, deste modo: 
Trata-se de um fluxo de decisões públicas, orientado a manter o equilíbrio social ou a introduzir desequilíbrios destinados a modificar essa realidade. Decisões condicionadas pelo próprio fluxo e pelas reações e modificações que elas provocam no tecido social, bem como pelos valores, ideias e visões dos que adotam ou influem na decisão. É possível considerá-las como estratégias que apontam para diversos fins, todos eles, de alguma forma, desejados pelos diversos grupos que participam do processo decisório.

Não obstante este sucinto conceito, o referido tema é de grande complexidade, pois a formulação, implantação e execução das políticas públicas demandam a conjugação de vários fatores de ordem social, política e econômica. A criação de políticas públicas, pois, é um processo complexo, que envolve vários segmentos sociais, os quais interagem, dialeticamente, buscando a defesa de determinados interesses (particulares e/ou coletivos), mas desde que tenham conotação social. Mais uma vez, cabe aqui citar as palavras de Saraiva (2007, p.29):

É importante destacar que o processo de política pública não possui uma racionalidade manifesta. Não é uma ordenação tranquila na qual cada ator social conhece e desempenha o papel esperado. Não há, no presente estágio de evolução tecnológica, alguma possibilidade de fazer com que os computadores - aparelhos de racionalidade lógica por excelência - sequer consigam descrever os processos de política.

Nesse sentido, na formulação de políticas públicas participam indivíduos que têm o poder de influenciar, direta ou indiretamente, a escolha e implementação da melhor política de governo, capaz de atender a demanda social posta em debate. Tais indivíduos podem ser chamados de "atores sociais", justamente por desempenharem "papel" relevante na determinação das políticas públicas. Estes "atores" ainda podem ser classificados em "atores públicos" e em "atores privados", a depender do tipo de interesse envolvido.

Para que uma política pública seja implementada, além de todo o ciclo de diálogos envolvendo os "atores sociais" na escolha da política mais adequada a determinado segmento social, é também preciso verificar qual o impacto econômico e financeiro será infligido aos cofres públicos. Isso porque, toda atividade estatal, seja no campo administrativo, operacional e social, demanda o aporte de recursos humanos e financeiros.

Os primeiros (recursos humanos) são os agentes públicos que compõem os quadros profissionais da Administração, exercendo cargos ou funções públicas. Já os segundos (recursos financeiros), por sua vez, são o conjunto de bens (patrimônio) e dinheiro (receita pública) de que dispõe a Administração para a operacionalização dos seus planos e programas. Os bens públicos são aqueles incorporados ao patrimônio da Administração, seja através de aquisição direta (processo licitatório) ou indireta (dação em pagamento de bens móveis ou imóveis) e que são utilizados pelos agentes públicos na execução das atividades administrativas, a exemplo dos prédios públicos de uso especial, veículos de transporte, computadores etc. Os recursos financeiros propriamente ditos (receita pública) são os ingressos pecuniários aos cofres públicos, 
utilizados para manutenção de toda a "máquina pública", com o pagamento de remunerações e aquisição de bens, por exemplo.

\subsection{Orçamento público e o princípio do mínimo existencial}

Conforme apontado alhures, toda atividade estatal demanda o dispêndio de recursos, sejam eles humanos e/ou financeiros. O Orçamento Público trata, justamente, desta última modalidade de recursos. Assim, o Orçamento Público é o instrumento normativo-financeiro que trata da Atividade Financeira Estatal, ou seja, é o meio pelo qual o Poder Público prevê suas receitas e fixa suas despesas, visando o atendimento dos programas e ações derivados do Plano de Governo. Logo, sobre toda atividade estatal incidem reflexos de ordem financeira, sendo o Orçamento Público o começo e o fim de qualquer ação do Poder Público.

Segundo Leite (2012, p.17), o Fenômeno Financeiro Estatal:

Estuda a finalidade principal do Estado, que é a realização do bem comum, e a consequente necessidade de desenvolver diversas atividades, chamadas atividades estatais, para que esse bem geral seja alcançado. Desse modo, o Estado não visa a proteção das necessidades individuais ou coletivas do homem, mas, sim, a satisfação de suas necessidades públicas.

Segundo o conceito clássico de Orçamento Público, este se tratava apenas de uma lei em sentido meramente formal, ou seja, apenas transvestia-se de lei, sendo desprovido dos atributos caracterizadores das verdadeiras Fontes do Direito (abstração, generalidade e coercibilidade). Melhor dizendo, o Orçamento Público nada obrigava ao que nele estava previsto, não criava nem inovava no ordenamento jurídico, sendo apenas um ato administrativo concreto, onde eram previstas as receitas públicas e fixadas as despesas, recebendo status de "lei" somente por ter se submetido ao respectivo processo legislativo.

Hodiernamente, o Orçamento Público vem ganhando outra fisionomia. Sua importância é deveras reconhecida, podendo ser visto como a lei que programa a vida financeira do Estado, amoldando-se as respectivas necessidades públicas. É verdade que ainda é bastante discutível acerca da obrigatoriedade, por parte do administrador público, da execução das despesas nele previstas, mas, para que tais despesas sejam executadas, necessariamente, elas devem estar previstas (fixadas) na Lei Orçamentária.

Mais uma vez citando Leite (2012, p.45), pode-se entender o Orçamento Público como:

Uma lei que autoriza os gastos que o Governo pode realizar durante um período determinado de tempo, discriminando detalhadamente as obrigações que deva concretizar, com a previsão concomitante dos ingressos necessários para cobri-las.

Em razão disso, podemos dizer que a "equação" financeira-estatal funciona tendo o Orçamento Público como o instrumento legal orientado de toda a atividade 
financeira, estando previsto o total da receita a ser arrecadada no exercício fiscal, e a determinação das ações e programas onde tais recursos deverão ser aplicados.

Não obstante os significativos números de arrecadação (receita pública) divulgados todos os anos, tais recursos não são ilimitados, não dispondo o Poder Público da quantia necessária para atender a todas as demandas sociais. Em razão desse cenário de limitação financeira, o Estado precisa fazer um importante juízo de seletividade e distributividade na aplicação desses recursos, no sentido de "escolher" quais ações e programas devem ser implantados de modo a atingir o maior número de segmentos sociais.

Nesse contexto, o Estado não pode (ou não consegue) atender, satisfatoriamente, todos os anseios da sociedade, devendo observar, na aplicação das políticas públicas, o binômio necessidade/possibilidade. À justificativa do Poder Público para desatendimento de tais necessidades públicas é dado o nome de "Reserva do Possível", ou seja, o Poder Público, a priori, não pode ir além das forças dos recursos de que dispõe para realização das suas atividades. É forçoso reconhecer que, em face de tal situação, fatalmente, algumas demandas sociais deixarão de ser contempladas pela atuação Estatal.

Apesar da Reserva do Possível estabelecer limites à efetivação das políticas públicas, restringindo os recursos disponíveis para sua concretização, esse princípio não pode ser utilizado de acordo com a conveniência e vontade pessoal do Administrador Público, como simples desculpa para sua inércia, ao alvedrio do Princípio do Mínimo Existencial. Esse, por sua vez, consubstancia-se nas condições mínimas de existência humana. Conceituando o Mínimo Existencial, o já aqui citado Ministro Luís Roberto Barroso assim leciona: "São as condições elementares de educação, saúde e renda que permitam, em uma determinada sociedade, o acesso aos valores civilizatórios e a participação esclarecida no processo político e no debate político" (BARROSO, 2011, p. 10).

Logo, em detrimento do mínimo necessário a uma sobrevivência digna, não pode o Poder Público furtar-se ao cumprimento de suas obrigações para com a sociedade, mesmo que esteja engessado pelos ditames normativos do Orçamento Público. Melhor dizendo, os princípios que norteiam a Atividade Financeira Estatal, em especial, o do equilíbrio entre receita e despesa, não podem ser invocados pelo Administrador Público, para escusar-se de efetivar determinada ação ou programa, que vise garantir, ao menos com o mínimo de efetividade, a concretização de direitos sociais.

\subsection{Intervenção judicial e o princípio da separação dos poderes}

Um dos pilares que sustentam o Estado Democrático de Direito é o que se convencionou chamar de Princípio da Separação dos Poderes. Teoria preconizada por Aristóteles e aperfeiçoada pelo Barão de Montesquieu, a separação do Poder Político em funções estatais (Legislativa, Executiva e Judiciária) é mais do que uma forma de organização do Estado. É uma garantia político-institucional, voltada para a proteção do cidadão, contra o arbítrio do Poder Público.

Consagrado na grande maioria dos Estados democráticos existentes, o Princípio da Separação dos Poderes está expressamente previsto no Artigo $2^{\circ}$, do texto da Constituição Federal brasileira, de 05 de outubro de 1988, estabelecendo que são 
Poderes da União, independentes e harmônicos entre si, o Legislativo, o Executivo e o Judiciário. A harmonia e a independência entre eles é o sustentáculo do chamado Estado Democrático de Direito, que significa, a grosso modo, um Estado onde os direitos individuais são respeitados, na medida em que veda possíveis arbitrariedades, resguardando as instituições democráticas e, especialmente, as liberdade públicas (FERNANDES, 2012).

Chamados também de "Poderes Constituídos da República", a expressão "separação de poderes" é utilizada de forma equivocada (apesar de largamente empregada pelos autores constitucionalistas), uma vez que, segundo a própria Constituição Federal (Parágrafo Único, do Artigo $1^{\circ}$ ), o "Poder" é uno e indivisível, cujo titular é o povo brasileiro. Trata-se, na verdade, de simples divisão das funções atribuídas ao Estado: a Legislativa, a Executiva e a Judiciária (BULOS, 2012, p. 520). À primeira, cabe a feitura das Leis e demais atos normativos gerais e abstratos; à segunda, foi atribuída a função administrativa, de direção da máquina pública; e, finalmente, à última função, compete dirimir os conflitos de interesse entre os indivíduos, aplicando o Direito Positivo ao caso concreto.

Essas atribuições originárias são chamadas de funções Típicas, ínsitas à natureza política de cada um dos Poderes Constituídos. Mas também lhes são atribuídas pela Constituição Federal outras funções, anômalas ao seu escopo, porém indispensáveis à manutenção da harmonia e independência entre os Poderes. São as chamadas funções Atípicas, as quais, aliadas as Típicas, compõem o sistema de "Freios e Contrapesos", que garantem a independência das Funções Estatais. Segundo Bulos (2012, p.522):

A doutrina clássica da separação de Poderes, preconizada por
Montesquieu, que distingue a legislação, a administração e a
jurisdição, atribuídas a órgãos distintos e independentes entre si, e que
impregnou a Declaração dos Direitos do Homem e do Cidadão de
1789 (art. 16) e a nossa Carta de $1988\left(\right.$ art. $2^{\circ}$ ), deve ser vista, no
Brasil, pela ótica da relatividade. No Brasil, não há separação absoluta
das funções legislativa, executiva e judiciária, as quais não se
afiguram estanques entre si.

Em relação às políticas públicas, sua elaboração, implantação e execução são atividades inegavelmente ligadas às funções típicas do Poder Executivo e do Poder Legislativo, haja vista a forte influência política que permeia as respectivas ações e programas. Ao Legislativo, como poder representante do povo, cabe receber as demandas sociais (necessidades coletivas), sintetizá-las, e consubstanciá-las em leis, dando origem a direitos públicos subjetivos, cuja titularidade pertence, justamente, a toda sociedade. Já ao Poder Executivo, detentor da função precípua de administrar e gerir a "coisa pública", compete, tomando como fundamento e orientação as leis elaboradas pelo Parlamento, efetivar, em sentido material, os direitos nelas previstos.

Desse modo, a legitimação dos Poderes Executivo e Legislativo, na consecução das políticas públicas, deriva do contexto político que os envolve, uma vez que são os únicos Poderes da República, a exceção do Judiciário, cujos membros são eleitos democraticamente pelo povo. Essa legitimação ganha destaque, quando da atuação do Poder Executivo, em razão de deter a função precípua de conduzir a Administração Pública, tendo todo o aparato técnico-institucional para receber, processar, e 
desenvolver as ações e programas necessários ao atendimento dos passivos sociais. Melhor dizendo, seria o próprio povo, através de seus representantes eleitos, que trata acerca dos direitos sociais e das respectivas políticas públicas de efetivação (GOMES, 1997).

Em face disso, se construiu o paradigma da não ingerência, por iniciativa própria ou mesmo provocada, do Poder Judiciário ou outro órgão semelhante, a exemplo do Ministério Público, na efetivação de tais direitos. E dois seriam os principais argumentos para tanto. Em primeiro lugar, como os membros destes órgãos não são escolhidos pela sociedade, os mesmos não deteriam legitimidade para atuar em tal seara, tomando as vezes do Poder Executivo e do Legislativo. Outro ponto que fortalece o referido impedimento, é que a elaboração de políticas públicas deriva de decisões políticas, com ampla participação da sociedade, e dentro das possibilidades financeiras do Poder Público. Assim, não poderia o Poder Judiciário, que, num primeiro momento, não conheceria o alcance dos recursos públicos disponíveis, nem das necessidades da coletividade, indicar qual política pública (ação e/ou programa) deveria ser desenvolvida.

Contudo, esse paradigma da falta de legitimação do Poder Judiciário para intervir em tais casos começa a receber novos contornos, em especial por se tratar de uma discussão acerca da efetivação de direitos fundamentais, tomando como fundamento o Princípio do Mínimo Existencial, o qual postula que o Poder Público tem o dever de garantir as mínimas condições de desenvolvimento das potencialidades do ser humano.

Aqui, mais uma vez, podemos citar as palavras de Leivas (2006, p.95), sobre a colocação levantada no parágrafo anterior. Senão vejamos:

No modelo aqui desenvolvido, que segue a teoria externa das restrições, os princípios democrático e da separação dos poderes, que efetivamente conferem aos poderes Legislativo e Executivo uma legitimação privilegiada para a conformação e execução dos direitos fundamentais sociais, são princípios constitucionais que restringem amiúdes os direitos fundamentais sociais "prima facie", porém não funcionam como obstáculos à efetividade destes direitos em caso de omissão ou ação insuficiente, inadequada ou desnecessária dos Poderes Legislativo e Executivo.

Assim, mesmo reconhecendo as restrições impostas pelo Princípio da Separação dos Poderes ao Poder Judiciário, não permitindo sua intervenção nas decisões políticas do Executivo e do Legislativo, mormente quando essas tratarem do juízo de oportunidade e conveniência na elaboração de ações e programas de governo, estes impedimentos não alcançariam a efetivação de políticas públicas, que tivessem como escopo a concretização de direitos sociais, em atenção ao Princípio do Mínimo Existencial.

\section{Procedimentos metodológicos}

O ensino universitário superior (acadêmico) está estruturado pelo "tripé" ensino, extensão e pesquisa, sendo esta última atividade destinada à produção de novos 
conhecimentos científicos, os quais servirão de apoio e sustentação às demais ações (ensino e extensão).

A pesquisa procura respostas para questionamentos acerca de fatos $\mathrm{e}$ acontecimentos ligados, ora à natureza (ciências naturais e biológicas), ora à atividade humana (ciências sociais). Para tanto, a atividade de pesquisa lança mão de procedimentos metodológicos (métodos e técnicas), que irão instrumentalizar o pesquisador, guiando-o às respostas das referidas perguntas. Essas respostas (soluções à problematização apontada), ao final, irão compor o conhecimento científico perquirido pelo pesquisador, conhecimento este derivado justamente da investigação ordenada e organizada da realidade (ZANELLA, 2012).

Assim como qualquer processo, a pesquisa científica subdivide-se num conjunto ordenado de ações, com vistas a alcançar determinado objetivo, ou seja, precisa ser devidamente planejada e executada. Ao pesquisador cabe estabelecer quais os atos (etapas) irão compor sua atividade de pesquisa, os quais, sinteticamente, podem ser divididos em coleta e análise dos dados relativos ao objeto em estudo, discussão acerca destes dados, e divulgação do(s) resultado(s) obtido(s).

Para o presente trabalho, o qual tem como escopo a análise e discussão da jurisprudência dos principais tribunais brasileiros acerca da intervenção jurisdicional na efetivação de políticas públicas, fizemos uso de uma pesquisa qualitativa, analisando decisões judiciais (documentos internos) do Supremo Tribunal Federal e do Superior Tribunal de Justiça, disponíveis para livre acesso e consulta nos respectivos endereços eletrônicos na internet (fonte), além do estudo de vasta bibliografia pertinente, a fim de descrever como estas Cortes Superiores enfrentam o referido tema.

Nesse momento, se faz oportuno tecer algumas considerações sobre os referidos elementos de análise (dados e fontes), no intuito de esclarecer determinados conceitos e expressões aqui utilizados.

Os dados coletados para análise (documentos) são decisões exaradas pelo Supremo Tribunal Federal e Superior Tribunal de Justiça, acerca do tema referente às políticas públicas e aos direitos sociais. As decisões tomadas por estas Cortes possuem certas peculiaridades que as diferem das demais instâncias ordinárias, em razão da sua competência constitucionalmente estabelecida.

Em primeiro lugar, o Supremo Tribunal Federal (STF) é o órgão de cúpula do Poder Judiciário brasileiro, cuja principal função é a guarda da Constituição Federal (Art. 102, da CF/1988), cabendo a ele interpretá-la e resolver em definitivo as questões a ela referentes. Os principais instrumentos de proteção da Constituição pelo STF são o sistema de controle de constitucionalidade, através das respectivas ações correspondentes, e do julgamento dos Recursos Extraordinários que lhe são interpostos, aos quais seja reconhecida a Repercussão Geral, ou seja, quando a questão discutida tenha reflexos de ordem constitucional (Art. 102, inciso I, alínea "a", e inciso III, alíneas "a", "b", "c" e "d", da CF/1988).

O Superior Tribunal de Justiça (STJ), por sua vez, é o órgão responsável por uniformizar a interpretação da Legislação Federal (infraconstitucional), ou seja, quando há uma questão legal controvertida no âmbito das Cortes Ordinárias, cabe ao STJ, através do instrumento chamado Recurso Especial, dar a interpretação infraconstitucional adequada (Art.105, inciso III, alíneas "a", "b" e "c", da CF/1988). 
O diferencial dessas decisões (Ações de Controle de Constitucionalidade, Recurso Extraordinário e Recurso Especial) é o caráter geral (extra partes) e vinculante que elas recebem, repercutindo no ordenamento jurídico nacional como um todo, ao passo que, nas instâncias ordinárias, tais decisões afetam apenas as partes em litígio (inter partes). Melhor dizendo, quando o STF e o STJ decidem em sede destes instrumentos processuais, tais decisões possuem caráter geral e definitivo, assemelhando-se a uma determinação legal (FERNANDES, 2012).

Nesse ponto é que reside a importância dos referidos dados para a presente pesquisa, pois apenas essas decisões, em sede de Controle de Constitucionalidade, Recurso Extraordinário e Recurso Especial, possuem força vinculante para atingir o Poder Executivo, ou seja, ao reconhecer a inexistência (omissão) e/ou deficiência (negligência) de alguma política pública, a decisão judicial pode determinar a sua implementação.

Através de consulta sistemática nos sítios eletrônicos das referidas Cortes, foram selecionadas decisões em processos nos quais foram tratados os temas aqui discutidos, que serviram como base de dados para análise no presente trabalho. A referida consulta teve como parâmetro de busca as expressões "políticas públicas", "direitos sociais", "intervenção judicial" e "separação dos poderes".

A referida consulta resultou na disposição de 16 (dezesseis) decisões emitidas pelo STF, as quais foram proferidas em sede de Controle de Constitucionalidade e de Recurso Extraordinário, das quais foram selecionadas 05 (cinco), cujo mérito envolveu a discussão sobre a efetivação de direitos relacionados ao acesso à educação infantil em creches e pré-escolas, à saúde, e também sobre a garantia de acessibilidade para pessoas portadoras de necessidades especiais, além de enfatizarem a legitimidade do Poder Judiciário para intervir nos atos do Poder Executivo. Também foram colacionadas aqui 04 (quatro) decisões do STJ, as quais foram pronunciadas em julgamentos de Recursos Especiais.

Cada uma destas decisões versa sobre pontos relacionados ao tema aqui estudado (políticas públicas e efetivação de direitos fundamentais), mormente no que tange à intervenção do Poder Judiciário, e o dever de prestação de serviços públicos adequados e de qualidade pelo Poder Público.

\section{Resultados e discussão}

Conforme apontado no tópico anterior, resultaram da referida consulta um total de 20 (vinte) decisões judiciais, relativas ao tema das políticas públicas, sendo 16 (dezesseis) emitidas pelo STF e 04 (quatro) pelo STJ. Discutiremos cada um destes pronunciamentos, considerando a sua natureza jurídica e os argumentos utilizados pelas respectivas Cortes, para fundamentar a decisão. Iniciaremos a discussão pelos cinco julgados selecionados do Supremo Tribunal Federal, em razão de tratar-se do órgão maior do Poder Judiciário brasileiro e guardião da Ordem Constitucional. Ato contínuo, passaremos à análise das decisões do Superior Tribunal de Justiça.

\subsection{Análise das decisões do Supremo Tribunal Federal (STF)}

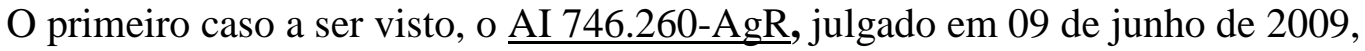
trata do julgamento de um recurso, onde o estado do Rio de Janeiro ataca decisão do 
Tribunal de Justiça local a qual não deu seguimento a um Recurso Extraordinário, interposto para o STF. Neste processo, foi discutida a impossibilidade de intervenção do Poder Judiciário, para anular um ato administrativo do Poder Executivo, em razão do Princípio da Separação dos Poderes.

Contudo, a Ministra Cármen Lúcia, relatora do recurso, destacou que é pacífico entre os demais ministros do STF o entendimento de que compete ao Poder Judiciário a análise da legalidade e da constitucionalidade dos atos administrativos. Foram as palavras da Ministra em seu voto:

Por fim, cumpre ressaltar que o Supremo Tribunal Federal firmou entendimento no sentido de que compete ao Poder Judiciário a análise da legalidade e constitucionalidade dos atos administrativos (AI 746.260-AgR Rel. Min. Cármen Lúcia, julgamento em 9-6-2009, Primeira Turma, DJE de 7-8-2009).

A próxima decisão analisada, a qual já nos referimos alhures, foi proferida no julgamento da ADI 2.649, julgada em 08 de maio 2008, também de relatoria da Ministra Cármen Lúcia. Trata-se de uma Ação Direita de Inconstitucionalidade, na qual a Associação Brasileira das Empresas de Transporte Rodoviário Intermunicipal, Interestadual e Internacional de Passageiros (ABRATI), questiona a constitucionalidade da Lei $\mathrm{n}^{\circ}$ 8.899, de 29 de junho de 1994, que concede gratuidade no sistema de transporte coletivo interestadual às pessoas portadoras de deficiências. A referida entidade de representação argumentou que a referida lei feriu os princípios da Ordem Econômica, da Isonomia, da Livre Iniciativa, do Direito de Propriedade, além da ausência da respectiva fonte de custeio para a concessão do referido benefício.

Essa Ação Declaratória de Inconstitucionalidade foi julgada improcedente pelo STF, sob os argumentos de que o Brasil assinou, em 30 de julho de 2007, a Convenção sobre os Direitos das Pessoas com Deficiência, comprometendo-se a adotar as medidas cabíveis para efetivação dos compromissos assumidos. Ademais, salientou que a Lei $\mathrm{n}^{\circ}$ 8.899 faz parte das políticas públicas para inserir os portadores de necessidades especiais na sociedade e objetiva a igualdade de oportunidades e humanização das relações sociais.

Vale aqui destacarmos importante passagem do voto da Ministra Cármen Lúcia nesse julgamento, senão vejamos:

Devem ser postos em relevo os valores que norteiam a Constituição e que devem servir de orientação para a correta interpretação e aplicação das normas constitucionais e apreciação da subsunção, ou não, da Lei 8.899/1994 a elas. Vale, assim, uma palavra, ainda que brevíssima, ao Preâmbulo da Constituição, no qual se contém a explicitação dos valores que dominam a obra constitucional de 1988. Não apenas o Estado haverá de ser convocado para formular as políticas públicas que podem conduzir ao bem-estar, à igualdade e à justiça, mas a sociedade haverá de se organizar segundo aqueles valores, a fim de que se firme como uma comunidade fraterna, pluralista e sem preconceitos (ADI 2.649, voto da Rel. Min. Cármen Lúcia, julgamento em 8-5-2008, Plenário, DJE de 17-10-2008). 
Outra decisão tomada pela nossa Suprema Corte, no ARE 639.337-AgR, julgado em 23 de agosto de 2011, cuja relatoria foi do Ministro Celso de Mello, abordou o tema da Reserva do Possível e do Princípio do Mínimo Existencial. Trata-se de um recurso interposto contra decisão que obrigara o município de São Paulo a matricular crianças em escolas e/ou creches de ensino infantil, próximas à sua residência ou ao local de trabalho de seus pais.

O município argumentou que o Poder Judiciário não possui legitimidade para intervir nas decisões políticas dos entes públicos, sobretudo na implantação de determinada ação ou programa de governo, por versar diretamente sobre gastos públicos. Todavia, o STF não deu provimento ao recurso, defendendo que o Judiciário é constitucionalmente legitimado a agir em face das omissões do Poder Público, quando se trata da efetivação de direitos sociais, e que também não poderia alegar o município ausência de receita para efetivar políticas públicas, garantidoras do Mínimo Existencial.

Transcrevemos parte do voto do Ministro Celso de Mello, bastante ilustrativo do tema abordado. Vejamos:

A cláusula da reserva do possível - que não pode ser invocada, pelo Poder Público, com o propósito de fraudar, de frustrar e de inviabilizar a implementação de políticas públicas definidas na própria Constituição - encontra insuperável limitação na garantia constitucional do mínimo existencial, que representa, no contexto de nosso ordenamento positivo, emanação direta do postulado da essencial dignidade da pessoa humana. A noção de 'mínimo existencial', que resulta, por implicitude, de determinados preceitos constitucionais (CF, art. $1^{\circ}$, III, e art. $3^{\circ}$, III), compreende um complexo de prerrogativas cuja concretização revela-se capaz de garantir condições adequadas de existência digna, em ordem a assegurar, à pessoa, acesso efetivo ao direito geral de liberdade e, também, a prestações positivas originárias do Estado, viabilizadoras da plena fruição de direitos sociais básicos, tais como o direito à educação, o direito à proteção integral da criança e do adolescente, $\mathrm{o}$ direito à saúde, o direito à assistência social, o direito à moradia, $\mathrm{o}$ direito à alimentação e o direito à segurança. Declaração Universal dos Direitos da Pessoa Humana, de 1948 (Artigo XXV) (ARE 639.337-AgR, Rel. Min. Celso de Mello, julgamento em 23-8-2011, Segunda Turma, DJE de 15-9-2011).

$\mathrm{O}$ quarto caso aqui trazido é o tratado no RE 642.535-AgR, relatado pelo Ministro Luiz Fux e julgado em 05 de fevereiro de 2013, cuja discussão do mérito versou sobre a possibilidade do Poder Judiciário determinar ao Poder Executivo a adoção de providências administrativas visando a melhoria da qualidade da prestação do serviço de saúde por hospital de rede pública.

O estado do Amapá interpôs o referido recurso, contra decisão que determinara que tomasse as medidas necessárias para melhoria da qualidade da prestação do serviço de saúde, por hospital de sua rede pública. Defendeu em suas razões que a referida decisão desrespeitou o princípio da Separação dos Poderes e da Reserva do Possível. No entanto, o Supremo Tribunal Federal não acolheu seus argumentos, afirmando não ter havido o desrespeito a tais princípios. Argumentou ainda o STF que, em se tratando do direito à saúde, a intervenção judicial é possível em hipóteses como a relatada, na qual o 
Poder Judiciário não está inovando na ordem jurídica, mas tão somente determinando ao Poder Executivo o cumprimento de políticas públicas previamente definidas (RE 642.536-AgR, Rel. Min. Luiz Fux, julgamento em 5-2-2013, Primeira Turma, DJE de 27-2-2013).

O último caso extraído da jurisprudência do Supremo Tribunal Federal e apresentado neste trabalho é o tratado no RE 436.996-AgR, também relatado pelo Ministro Celso de Mello e julgado em 22 de novembro de 2005. O município de Santo André, no interior de São Paulo, recorreu de decisão que lhe obrigara a garantir o atendimento em creches e em pré-escolas a crianças de até seis anos de idade. Nas suas razões do recurso, o ente público também se socorreu dos Princípios da Reserva do Possível e da Separação dos Poderes, para eximir-se da obrigação de garantir o aceso à educação infantil para as referidas crianças.

No seu relatório, o Ministro Celso de Mello salientou que os entes públicos não podem demitir-se de prestarem as políticas públicas necessárias à garantia do acesso à educação, especialmente os municípios, aos quais, segundo a Constituição Federal de 1988, cabe atuar prioritariamente na educação infantil. Aduziu ainda que a educação infantil não deve submeter-se a avaliações meramente discricionárias da Administração Pública, nem a razões de pragmatismo governamental.

Transcreveremos aqui importante trecho do voto do Ministro Celso de Mello, no qual o jurista discorre sobre a legitimidade para implantação de políticas públicas. Vejamos:

\begin{abstract}
Embora resida, primariamente, nos Poderes Legislativo e Executivo, a prerrogativa de formular e executar políticas públicas, revela-se possível, no entanto, ao Poder Judiciário, determinar, ainda que em bases excepcionais, especialmente nas hipóteses de políticas públicas definidas pela própria Constituição, sejam estas implementadas pelos órgãos estatais inadimplentes, cuja omissão - por importar em descumprimento dos encargos político-jurídicos que sobre eles incidem em caráter mandatório - mostra-se apta a comprometer a eficácia e a integridade de direitos sociais e culturais impregnados de estatura constitucional (RE 436.996-AgR, Rel. Min. Celso de Mello, julgamento em 22-11-05, Segunda Turma, $D J$ de 3-2-2006).
\end{abstract}

Discutiremos, doravante, as decisões proferidas pelo Superior Tribunal de Justiça. Conquanto este Órgão não possua competência para interpretar e dizer em definitivo sobre as normas constitucionais (competência do STF), em sede de Recurso Especial, o STJ tem competência para uniformizar a interpretação sobre toda legislação infraconstitucional, também possuindo suas decisões natureza vinculante e geral.

\title{
4.2 Análise das decisões do Superior Tribunal de Justiça (STJ)
}

O primeiro caso aqui trazido se refere ao julgamento do REsp.1488639-SE, cuja relatoria foi do Ministro Herman Benjamin e julgado em 21 de novembro de 2014, no qual foi discutido o dever por parte dos entes públicos de fornecer medicamentos, em casos de emergências de risco de morte. O STJ, nesse processo, defendeu a tese jurídica que a obrigação de fornecer medicamentos pelos entes públicos é corolário do direito fundamental à saúde, e que tal dever é responsabilidade solidária entre os entes políticos 
(União, Estados e Municípios), podendo o cidadão demandar contra qualquer um destes.

Enfatizou, ainda, o Ministro Relator que é pacífico entre os demais membros daquela Corte que, nos casos de fornecimento de medicamentos, é possível inclusive o bloqueio de contas públicas e a fixação de multa diária, na hipótese de descumprimento de ordem judicial que determine o fornecimento. Também argumentou que não é possível ao ente público opor o Princípio da Reserva do Possível, em detrimento do Mínimo Existencial, sendo fundamental a atuação judicial no controle da atividade administrativa. Vejamos passagem do referido voto do Ministro:

Não podem os direitos sociais ficar condicionados à boa vontade do Administrador, sendo de suma importância que o Judiciário atue como órgão controlador da atividade administrativa. Seria distorção pensar que o princípio da separação dos poderes, originalmente concebido com o escopo de garantia dos direitos fundamentais, pudesse ser utilizado justamente como óbice à realização dos direitos sociais, igualmente relevantes. Tratando-se de direito essencial, incluso no conceito de mínimo existencial, inexistirá empecilho jurídico para que o Judiciário estabeleça a inclusão de determinada política pública nos planos orçamentários do ente político, mormente quando não houver comprovação objetiva da incapacidade econômico-financeira da pessoa estatal (REsp.1488639/SE, Rel. Min. Herman Benjamin, julgamento em 20/11/2014, Segunda Turma, DJe 16/12/2014).

A próxima decisão foi tomada no bojo do julgamento do $\underline{\operatorname{AgRg} \text { no }}$ AREsp.362882-RN, julgado em 23 de outubro de 2014, e também relatado pelo Ministro Herman Benjamin. Este caso se refere a uma Ação Civil Pública, movida pelo Ministério Público do Rio Grande do Norte, contra o município de Natal, objetivando a condenação deste à construção e aparelhamento de um centro de armazenamento e distribuição de medicamentos. O Ministério Público ainda pediu a condenação do referido ente ao pagamento de uma indenização por danos morais coletivos, no montante de $\mathrm{R} \$ 5.000 .000,00$ (cinco milhões de reais).

O município de Natal se defendeu, aduzindo que já firmara um contrato de prestação de serviços com o Núcleo de Pesquisa em Alimentos e Medicamentos (NUPLAN), da Universidade Federal do Rio Grande do Norte, para atender a referida demanda.

Ao analisar o caso, o STJ entendeu que não houve "omissão inescusável", por parte do município de Natal, que autorize a intervenção jurisdicional no controle de políticas públicas, uma vez que o referido contrato com o NUPLAN estava em pleno vigor e atendendo sem maiores problemas a referida demanda. Contudo, o Tribunal reiterou sua posição, no sentido da possibilidade de ser exercido controle judicial de políticas públicas em caso de omissão injustificada do Estado, não obstante sua não aplicação ao presente caso. Transcrevemos abaixo trecho da referida decisão:

O controle jurisdicional de políticas públicas se legitima sempre que a "inescusável omissão estatal" na sua efetivação atinja direitos essenciais inclusos no conceito de mínimo existencial. De acordo com a moldura fática desenhada pelo acórdão de origem, não se verifica omissão do Poder Público Municipal, que, "no intuito de evitar novos 
prejuízos, celebrou com a Universidade Federa do Rio Grande do Norte um contrato de prestação de serviços", sendo que "o próprio Ministério Público afirma, durante o deslinde processual que o referido contrato está sendo devidamente cumprido pelo Núcleo de Pesquisa em Alimentos e Medicamentos (NUPLAN) da Universidade Federal do Rio Grande do Norte, bem como tal avença foi renovada, cora vigência de 01.06.2011 a 30.05.2012", informação que foi confirmada pelo Procurador-Geral do Município. Nesse contexto, evidentemente não pode prosperar a tese ministerial que pretende impor ao Município a construção de obra pública desnecessária, uma vez que o principal objetivo perseguido pelo Parquet (acondicionamento dos medicamentos e seus insumos) já fora alcançado pelo convênio firmado entre o Município e a Nuplan (AgRg no AREsp 362882/RN, Rel. Min. Herman Benjamin, julgamento em 23/10/2014, Segunda Turma, DJe 27/11/2014).

A terceira decisão, aqui mostrada, foi proferida no julgamento do $\underline{\operatorname{AgRg} \text { no RMS }}$ 38966/SC (Recurso em Mandado de Segurança), decidido em 09 de setembro de 2014, cuja relatoria foi do Ministro Jorge Mussi. Este caso tratou do tema referente ao problema da superlotação carcerária e das péssimas condições de habitabilidade dos presídios. A Vigilância Sanitária de Santa Catarina, em inspeção realizada no Presídio Regional de Mafra, constatou que o local apresentava péssimas condições higiênicas para acomodação dos detentos. Em razão disto, o Juiz Corregedor da referida Comarca editou uma portaria, limitando o acesso de presos ao local.

O STJ, julgando o caso, referendou o entendimento, segundo o qual não há ingerência do Poder Judiciário nas atribuições de outro Poder, mormente com relação ao cumprimento das disposições constitucionais pertinentes. No caso, é atribuída ao Juiz da Execução Penal competência administrativa para fiscalizar e, até mesmo, intervir no sistema prisional. Mais uma vez, transcrevemos passagem elucidativa do referido julgado, acerca dos pontos aqui discutidos. Senão vejamos:

A Carta Constitucional estabelece como núcleo dos direitos fundamentais a dignidade da pessoa humana (art. $1^{\circ}$, III, da CF). Nesse aspecto, ainda que seja afastada, legalmente, a liberdade como resultado de um processo criminal, tal aspecto não importa, consequentemente, a abdicação da dignidade anteriormente referida, pois atributo inerente a todo ser vivente racional. (...)Uma vez provocada, a prestação jurisdicional efetuada pelo Poder Judiciário não implica interferência nas atribuições constitucionais do Poder Executivo, pois o sistema de freios e contrapesos assegura a independência e a harmonia referida no art. $2^{\circ}$ da Constituição Federal e concretiza, nas situações autorizadoras, como no presente caso, a dignidade da pessoa humana, meta central da Carta Magna de promoção do bem-estar do homem. O art. 66 da LEP (Lei 7.210/84) delega ao Juiz da Execução tarefas de natureza eminentemente administrativa, não apenas no aspecto de fiscalização, mas também de intervenção, se e quando necessário (AgRg no RMS 38966/SC, Rel. Min. Jorge Muss, julgamento em 09/09/2014, Quinta Turma, DJe 17/09/2014). 
O último caso aqui trazido, da lavra do Superior Tribunal de Justiça, é a decisão proferida no REsp 1367549/MG, julgado em 02 de setembro de 2014, de relatoria do Ministro Humberto Martins. Neste, assim como no segundo caso apresentado acima, foi proposta uma Ação Civil Pública, desta vez pelo Ministério Público de Minas Gerais, pleiteando a condenação do ente estatal na construção de uma usina de reciclagem de refugos da construção civil, que estejam causando danos ao meio ambiente. Entendeu o STJ, reiterando seu posicionamento acerca do tema, que, em situações excepcionais, pode o Judiciário intervir, a fim de garantir medidas assecuratórias a direitos essenciais, sem que isso configure violação ao Princípio da Separação dos Poderes.

Mais uma vez, vamos repassar trecho do voto do Ministro Humberto Martins, proferido no referido julgamento, que concatena o posicionamento acima exposto. Vejamos:

\begin{abstract}
Reconheço que em algumas situações é impossível estabelecer, num plano abstrato, qual a ordem de prioridades que a atividade administrativa deve tomar. Nestes casos, a identificação pela preferência de atuação estatal apenas poderia ser identificada na análise do caso. Todavia, ainda que abstratamente, não se pode deixar de reconhecer que alguns direitos, tais como a educação, a saúde e o meio ambiente equilibrado fazem parte de um núcleo de obrigações que o estado deve considerar como prioritárias. Deve ser afastada a aplicação da Súmula 7/STJ e reconhecido a ofensa ao artigo 333, I, do $\mathrm{CPC}$. Isto porque a Corte de origem faz referência a vários elementos probatórios que induzem - em tese - a existência de dano ambiental, considerando, também, que durante a tramitação do processo ocorreu significativa melhora no sistema de destinação dos resíduos sólidos, em especial, com aprovação da lei municipal regulamentando o tema. No entanto, apesar disso, o pleito do Ministério Público Estadual foi indeferido em razão da ausência de provas (REsp 1367549/MG, Rel. Min. Humberto Martins, julgamento em 02/09/2014, Segunda Turma, DJe 08/09/2014).
\end{abstract}

Tendo, pois, acima apresentado os trechos das decisões selecionadas para o presente estudo, a seguir, sintetizaremos os principais pontos nelas constantes, e buscaremos identificar quais os fundamentos utilizados pelos referidos Tribunais, na construção do seu entendimento predominante sobre o assunto. De antemão, já podemos verificar a prevalência da ideia de que, independente da intervenção jurisdicional, o Estado não pode furtar-se de empregar os meios necessários à concretização do bem comum, ou seja, competirá sempre ao Poder Público promover a efetivação dos direitos sociais, por meio das políticas públicas necessárias.

\title{
5. Considerações finais
}

De acordo com a análise feita dos referidos documentos, foi possível identificar um padrão (entendimento) adotado pelas Cortes Superiores, quando do tratamento do tema aqui trabalhado.

Diversos foram os casos em que o STF e o STJ legitimaram a intervenção do Judiciário na atividade administrativa do Poder Executivo, mas todas as situações analisadas trataram da omissão deste, em desprender esforços para concretizar o acesso 
a direitos essenciais pelas pessoas, mormente à saúde e à educação. Ainda podemos destacar que também foram objeto de julgamento os temas relativos às pessoas portadoras de necessidades especiais e à salubridade dos presídios brasileiros. Não obstante, em todos os julgados, o que se observou foi a necessidade da conjugação de três fatores, para autorizar a ingerência judicial nos assuntos de outros Poderes, quais sejam: a omissão administrativa frente à uma demanda social, ser esta omissão injustificável, e a demanda social referir-se a direitos constitucionalmente reconhecidos como essenciais.

É cediço que a Administração Pública não pode responder a todas as súplicas da população. Em algum momento, determinado serviço público deixará de atender aos seus usuários por algum problema de ordem administrativa ou financeira, ou sequer chegará a ser posto à disposição para fruição. São situações onde está caracterizada a omissão do Poder Público em implementar as ações e serviços necessários ao atendimento da sociedade. Em muitos casos, isto é justificável, haja vista as várias demandas sociais que o Estado precisa atender.

Todavia, a omissão estatal ensejadora da intervenção do judiciário, conforme vimos nas decisões acima apresentadas, é qualificada por ser inescusável. Ou seja, o Poder Público se omite porque não dispõe de meios para atender a determinada necessidade social (Reserva do Possível). Para que reste caracterizada a referida justificativa, deve o ente estatal demonstrar de forma cabal que deveras não dispõe dos recursos necessários.

Mesmo assim, conquanto demonstre o Poder Público não possuir meios suficientes para atender satisfatoriamente determinada necessidade pública, quando esta disser respeito a direitos essenciais (Mínimo Existencial), essa insuficiência não poderá ser oposta pela Edilidade, a justificar sua omissão. Todas as decisões acima mostradas tocam neste ponto, configurando que, para os Tribunais de cúpula do Brasil, o Estado não pode furtar-se a atender demandas que garantam o mínimo de dignidade à população.

Portanto, é possível considerar, com base na análise da jurisprudência adotada pelo Supremo Tribunal Federal e pelo Superior Tribunal de Justiça, dispostas nas decisões aqui apresentadas, que é legítima a intervenção judicial na atividade administrativa, sem que haja violado o Princípio da Separação dos Poderes, para que seja determinada a efetivação de determinada política pública, em prol de garantir o Mínimo Existencial. Para tanto, se faz necessária que a deficiência daquela atividade seja injustificável, e as correspondentes políticas públicas visem a assegurar direitos essenciais.

\section{Referências}

AZAMBUJA, Darcy. Teoria geral do estado. 4. ed. São Paulo: Globo, 2008.

BARROSO, Luiz Roberto. A dignidade da pessoa humana no direito constitucional contemporâneo: natureza jurídica, conteúdos mínimos e critérios de aplicação. Disponível em: <www.luisrobertobarroso.com.br/wpcontent/uploads/2010/12/Dignidade_texto-base_11dez2010.pdf>. Acesso em: 16 jan. 2015.

BRASIL, Constituição Federal de 1988. 15. ed. São Paulo: Saraiva, 2013.

BULOS, Uadi Lammêgos. Direito constitucional ao alcance de todos. 4. ed. São Paulo: Saraiva, 2012. 
DALARE, Dalmo de Abreu. Elementos da teoria geral do estado. 2. ed. São Paulo: Saraiva, 1998.

FERNANDES, Bernardo Gonçalves. Curso de direito constitucional. 4. ed. Salvador: JusPodvim, 2012.

GOMES, Luiz Flávio. A dimensão da magistratura no estado constitucional e democrático de direito. 2. ed. São Paulo: Revista dos Tribunais, 1997.

LEAL, Rogério Gesta. O controle jurisdicional de políticas públicas no Brasil: possibilidades materiais. In: SARLET, Ingo Wolfgang (Org.). Jurisdição e direitos fundamentais. Porto Alegre: Livraria do Advogado, 2005.

LEITE, Harrison. Manual de direito financeiro. 1. ed. Salvador: JusPodvim, 2012. LEIVAS, Paulo Gilberto Cogo. Teoria dos direitos fundamentais sociais. Porto Alegre: Livraria do Advogado, 2006.

SARAIVA, Enrique. Introdução à teoria da política pública. In: SARAIVA, Enrique; FERRAREZI, Elisabete (Org.). Políticas públicas; coletânea. Brasília: ENAP, 2007, v.1.

SUPERIOR TRIBUNAL DE JUSTIÇA. 2 $2^{\mathrm{a}}$ Turma. REsp.1488639/SE. Relator: Herman Benjamin. Data do julgamento: 20/11/2014. DJE de 16/12/2014. Disponível em:

$<$ https://ww2.stj.jus.br/processo/pesquisa/?termo=REsp+1488639\&aplicacao=processos .ea\&tipoPesquisa=tipoPesquisaGenerica\&chkordem=DESC\&chkMorto=MORTO $>$. Acesso em: jan. 2015.

SUPERIOR TRIBUNAL DE JUSTIÇA. 2a Turma. AgRg. no AREsp. 362882/RN. Relator: Herman Benjamin. Data do julgamento: 23/10/2014. DJE de 27/11/2014. Disponível em: $<$ https://ww2.stj.jus.br/processo/pesquisa/?termo=AREsp. $+362882 \&$ aplicacao=processo s.ea\&tipoPesquisa=tipoPesquisaGenerica\&chkordem=DESC\&chkMorto=MORTO>. Acesso em: jan. 2015.

SUPERIOR TRIBUNAL DE JUSTIÇA. 5a Turma. AgRg no RMS 38966/SC. Relator: Jorge Muss. Data do julgamento: 09/09/2014. DJE de 17/09/2014. Disponível em: $<$ https://ww2.stj.jus.br/processo/pesquisa/?termo=RMS+38966\&aplicacao=processos.ea \& tipoPesquisa=tipoPesquisaGenerica\&chkordem=DESC\&chkMorto=MORTO $>$.

Acesso em: jan. 2015.

SUPERIOR TRIBUNAL DE JUSTIÇA. $2^{\mathrm{a}}$ Turma. REsp 1367549/MG. Relator: Humberto Martins. Data do julgamento: 02/09/2014. DJE de 08/09/2014. Disponível em:

$<$ https://ww2.stj.jus.br/processo/pesquisa/?termo=.+REsp+1367549\&aplicacao=process os.ea\&tipoPesquisa=tipoPesquisaGenerica\&chkordem $=$ DESC\&chkMorto=MORTO $>$.

Acesso em: jan. 2015.

SUPERIOR TRIBUNAL DE JUSTIÇA. $1^{\text {a }}$ Turma. RE 642.536-AgR. Relator: Luiz Fux. Data do julgamento 05/02/2013. DJE de 27/02/2013. Disponível em: <http://redir.stf.jus.br/paginadorpub/paginador.jsp?docTP=TP\&docID=3442753>.

Acesso em: jan. 2015.

SUPREMO TRIBUNAL FEDERAL. $2^{\text {a }}$ Turma. ARE 639.337-AgR. Relator: Celso de Mello. Data do julgamento 23/08/2011. DJE de 15/09/2011. Disponível em: <http://redir.stf.jus.br/paginadorpub/paginador.jsp?docTP=AC\&docID=627428>.

Acesso em: jan. 2015.

SUPREMO TRIBUNAL FEDERAL. $1^{\text {a }}$ Turma. AI 746.260-AgR. Relatora: Cármen Lúcia. Data do julgamento: 09/06/2009. DJE de 07/08/2009. Disponível em: <http://redir.stf.jus.br/paginadorpub/paginador.jsp?docTP=AC\&docID=600552>.

Acesso em: jan. 2015. 
SUPREMO TRIBUNAL FEDERAL. Plenário. ADI 2.649. Relatora: Cármen Lúcia. Data do julgamento: 08/05/2008. DJE de 17/10/2008. Disponível em: <http://redir.stf.jus.br/paginadorpub/paginador.jsp?docTP=AC\&docID=555517>.

Acesso em: 16 jan. 2015.

SUPREMO TRIBUNAL FEDERAL. $2^{\text {a }}$ Turma. RE 436.996-AgR. Relator: Celso de Mello. Data do julgamento: 22/11/2005. DJE de 03/02/2006. Disponível em: <http://redir.stf.jus.br/paginadorpub/paginador.jsp?docTP=AC\&docID=343060>.

Acesso em: jan. 2015.

ZANELLA, Liane Carly Hermes. Metodologia de estudo e de pesquisa em administração. 2. ed. Florianópolis: Departamento de Ciências da Administração UFSC, 2012. 